\title{
Dark they were, and strange inside
}

\author{
A very blind date.
}

\section{Vaughan Stanger}

If it weren't for the boffins who resurrected the Large Hadron Collider I wouldn't be placing flowers on my best friend's grave. For once, Marcie followed my advice. I wish she hadn't.

Marcie's journey to the hereafter began when she leaned across my kitchen table and fixed me with the kind of look she usually reserves for guys with performance issues.

"You did what?"

"I signed up for Internet dating!"

"Why'd you do that, Jen?"

"Cos I'm thirty-five."

Marcie rolled her eyes. "You're just having a cold spell. Everyone gets those."

Excepting Marcie, of course. She's never had to go shopping to get men. Big boobs and Beyoncé hair do the job for her, whereas I rate as 'presentable' in a good light. Admittedly, I did select Attractive on the web-form, but then who wouldn't?

"Okay," Marcie said with a sigh. "Let's take a look."

I fired up my laptop. Marcie chuckled her way through the website's blurb.

"Fundamentals.com: your portal to a multiverse of love.' Yeah, right!"

I scrolled through my profile, highlighting those difficult-to-write personal bits. Marcie waved me onwards.

"Never mind that drivel. What about your ideal man?"

I showed her.

"I see you've selected Dark."

"So?"

"I'm just saying." Her expression suggested she remembered my adventures with Ahmed.

"I did also select Attractive and Solvent."

"Which will get you Tubby and Tightwad." Marcie shook her head before giving me a wink. "Go for it girl!"

"So, you gonna tell me what happened?"

I could tell Marcie was excited because she didn't make her usual crack about Botox even though I was frowning.

"Well, I turned up at All Bar One wearing my - "

"I know what you were wearing!"

I blushed but said nothing.

"What did he look like?"

"It's hard to say."

Marcie groaned. "You did pick one with a photo, right?"

I shook my head. "No, but ..."
"Have I taught you nothing?"

Quite the opposite in fact, but I wasn't about to say so. I sighed and continued my account.

"There were lots of men there, but no standalones. So I sat at a corner table and waited. After half an hour of cooling my heels, I was about to go when ... the best way I can put it is that I felt a presence. I couldn't see him properly or work out what he was saying; yet I knew someone was sat next to me. But take it from me, you feel a right fool talking to thin air, so pretty soon I made my excuses and left."

"Good call."

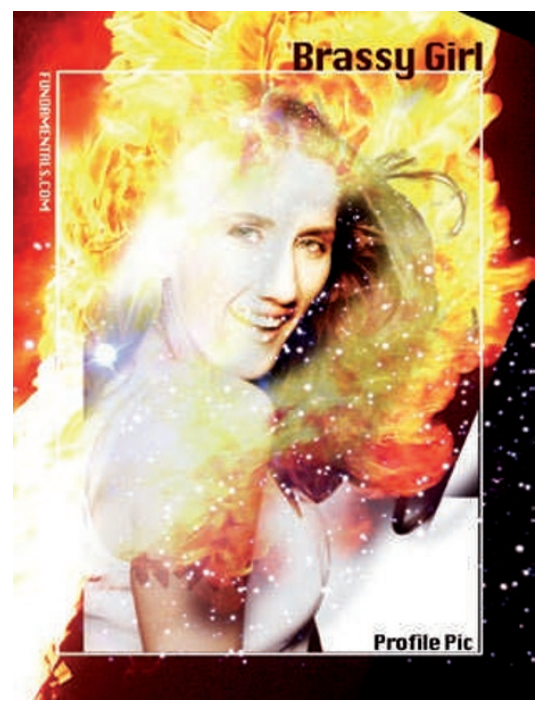

"But walking to the bus-stop, I could feel someone holding my hand. And when I finally got into bed, well..."

"Omigod, you pulled!" Marcie highfived me before asking the inevitable question: "So, was he any good?"

"Well, I did enjoy a very nice buzz."

I could tell Marcie wasn't convinced by the way she frowned at me. And who could blame her? But I knew I'd been to bed with a man, even if I hadn't actually clapped eyes on him at any stage.

I sipped my Chardonnay in silence while I awaited Marcie's verdict. Finally she delivered it.

"I bet he wasn't even dark, never mind tall and handsome."

On that point she couldn't have been more wrong.

The official news about our exotic friends broke the next day.

According to the hot-looking guy on Sky News, the Large Haddock Colander (the pride of CERN, as rechristened by
Marcie) hadn't opened up a planet-swallowing black hole as some had predicted, but it had definitely opened up a gateway to something. Within days, an MIT boffin announced that he'd built a dark matter delineator. Once the portable model hit the stores, my dates got a lot easier to spot. Fortunately I've always preferred the silent type.

I was dating my fourth dark guy by the time Marcie decided to join in the fun. My best friend asking me for dating advice; now that was a first!

"Okay, let's build your profile," I said. "And no, you can't upload those photos of you wearing nothing."

Marcie waggled her tongue at me before clicking her way through the options so expertly I wondered whether she was quite as inexperienced at this kind of thing as she claimed.

"I see you didn't select Dark," I said.

Marcie grinned like a snake hypnotizing a mouse.

"I'm looking for something a lot stronger than a 'very nice buzz!"

After three days with no phone calls or messages, I felt sick with worry. I texted Marcie a lurid description of my latest date, but didn't receive a reply. Either she was having such a good time it had left her speechless - another first - or her alley-cat morals had finally landed her in trouble.

As I drove into Marcie's street a fleet of fire engines and ambulances wailed past. Some hundred metres from her home, a police-boy with a volcanic complexion waved me back. He needn't have bothered. One glance at the huge pile of smoking rubble where Marcie's apartment block had once stood was enough.

Last I heard the death toll had topped 50. Needless to say, Fundamentals.com has withdrawn its Energetic option. It seems that some guys really are too dangerous to date, especially those made of antimatter. According to the boffins, the containment field needs more work.

Once the dust has settled I'll resume dating. Marcie would want me to. I miss her terribly but remember her well. Say what you like about my best friend, but she definitely went out with a bang.

Vaughan Stanger wishes to make it clear that any visits he might have made to dating websites were purely in the interests of researching this story. 